\title{
COMPARISON OF OPINIONS OF SLOVAK AND CZECH FEMALE MEDICAL STUDENTS ON HPV VACCINATION
}

\author{
Jozef Záhumenský1, Petra Pšenková1, Alexandra Nadzámová1, Paula Drabiščáková1, Lukáš Hruban², \\ Vít Weinberger ${ }^{2}$, Marian Kacerovský ${ }^{3}$, Erik Dosedla ${ }^{4}$ \\ ${ }^{1}$ Second Department of Gynaecology and Obstetrics, University Hospital Bratislava, Bratislava, Slovak Republic \\ ${ }^{2}$ Department of Obstetrics and Gynaecology, Masaryk University Hospital, Brno, Czech Republic \\ ${ }^{3}$ Department of Gynaecology and Obstetrics, University Hospital Hradec Králové, Faculty of Medicine in Hradec Králové, Charles University, \\ Hradec Králové, Czech Republic \\ ${ }^{4}$ Department of Obstetrics and Gynaecology, University of Pavel Jozef Šafárik, Hospital AGEL Košice-Šaca, Košice, Slovak Republic
}

\section{SUMMARY}

Objectives: This study aims to identify the differences in the use of HPV vaccination between female medical students in the Czech and Slovak Republics and their possible causes.

Methods: We performed a cross-sectional survey among female students of general medicine in all faculties of medicine in the Czech and Slovak Republics.

Results: We obtained 630 questionnaires from the Czech Republic and 776 questionnaires from the Slovak Republic. In the Czech Republic, $65.4 \%$ of female medical students underwent HPV vaccination, while in the Slovak Republic, the figure was $21.1 \%$. In the Czech Republic, residency and religion of students did not influence their rate of vaccination. However, in the Slovak Republic, village residency with less than 5,000 inhabitants lowered the probability of vaccination with $\mathrm{OR}=0.56(95 \% \mathrm{Cl}: 0.38-0.84)$, and the Catholic religion lowered the probability of vaccination with $\mathrm{OR}=0.40$ ( $95 \% \mathrm{Cl}: 0.28-0.57)$. Czech students were informed about the possibility of vaccination by a paediatrician in $55.7 \%$ of cases, while the figure for Slovak students was $26.8 \%$. In the Czech Republic, $75.7 \%$ of students participated in regular cervical oncologic screening, while in the Slovak Republic, the figure was $57.7 \%$. Vaccination of relatives would be recommended by $86.5 \%$ and $80.5 \%$ of Czech and Slovak students, respectively.

Conclusions: The adoption of an oncologic prevention programme and the more extensive propagation by paediatricians are probably the medical reasons for the higher HPV vaccination among Czech students. Demographic factors - village residency and religion - are also important.

Key words: HPV vaccination, cervical cancer prevention, medical students, survey

Address for correspondence: J. Záhumenský, Second Department of Gynaecology and Obstetrics, University Hospital Bratislava, Ruzinovska 6, 82106 Bratislava, Slovak Republic. E-mail: jozef.zahumensky@gmail.com

https://doi.org/10.21101/cejph.a5989

\section{INTRODUCTION}

Cervical carcinoma is one of the most common malignant tumors in women. From 2013 to 2016, a 33\% increase in the incidence of cervical carcinoma in situ was detected in the Czech Republic. Three thousand and one cases were reported in 2016, and the incidence was 55 cases per 100,000 women. In the group of invasive tumors, 822 cases were reported in 2016, and the incidence was 15.3 cases per 100,000 women (1). In the Slovak Republic, 594 cases of invasive cervical carcinoma were reported in 2011, with an incidence of 21.4 cases per 100,000 women. Two hundred and nineteen deaths were reported, which accounts for 7.9 cases per 100,000 women. More recent data are not available (2). For comparison, the prevalence of cervical carcinoma in the Czech Republic was 19.1 cases per 100,000 women in the same year (3).
Human papillomavirus (HPV) infection is one of the most common sexually transmitted infections in the world. It is associated with $99.7 \%$ of all cases of cervical cancer and is considered the leading cause of this type of cancer (4). Sexually active young adults stand a greater risk of being infected with HPV due to the high prevalence of HPV among this age group. The lifetime risk of acquiring a genital HPV infection is estimated to be at least $80 \%$ for sexually active women (5). There are currently three types of vaccines available and approved for the prevention of HPV, including the quadrivalent (HPV4), bivalent (HPV2), and nonavalent (HPV9) vaccines. All three vaccines protect against HPV types 16 and 18, which are linked to the majority of HPVrelated cancers (6). In the Czech Republic, HPV vaccination has been accessible since 2007 and was covered by public health insurance in 2012 (7). In the Slovak Republic, the vaccine was registered in 2007, and it was covered by public health insurance 
in 2019. The Czech and Slovak Republics were a single state (Czechoslovakia) until 1993. After separation, the healthcare system started to change in both countries and became different. In 2003, the Czech Republic adopted organized oncologic screening as part of a national oncologic programme. A similar programme was adopted by the Slovak Republic in 2018. Before then, the screening of cervical carcinoma was opportunistic, i.e. not organized $(8,9)$. In $2009,48 \%$ of Czech women and $20 \%$ of Slovak women attended cervical screening (10). In addition to healthcare organizations, a few differences between both countries can also be found in demographic parameters, individual opinions and religion status. Female medical students provide information about HPV vaccination in the future. Self-application is an important factor regarding the formation of patient's opinion. The aim of this study is to discover the differences in the rate of vaccination between female medical students in both countries, the causes of these differences and how vaccination rate can be influenced positively.

\section{MATERIALS AND METHODS}

Female medical students from all Czech and Slovak medical faculties were included in this study. The data were collected through an internet-based survey. The link to the questionnaire was sent through email to the members of associations of medical students of individual faculties in both countries. A fraction of the questionnaires was given in paper form personally during meetings of associations belonging to the Comenius University in Bratislava and Pavol Jozef Šafárik University in Košice. The questionnaire comprised 16 questions, of which three were fillin-the-blanks questions, and 13 were check box questions with the option of filling in the blank space. The questionnaire took about 10 minutes to complete. We demanded the email addresses of respondents to lower the risk of repeated filling. The data were collected from 1 February 2018 to 31 May 2018.

The first set of questions was designed to verify that the respondent is a female student of a medical faculty studying general medicine and was born and raised in the country of data collection. Slovak students studying in the Czech Republic and Czech students studying in the Slovak Republic were excluded from the study. Students of other courses (stomatology, paramedics) were also excluded.

The next set of questions focused on demographic data: age, population of the city of residence, city of birth, number of siblings, active practice of religion, and a parent as a medical professional. Then we asked if anyone from the respondent's close family or friends had suffered from severe cervical disease and whether the respondents attend cervical cancer screening regularly. Subsequent questions inquired about the specialist that informed the respondent about the option of HPV vaccination and her sources of information about vaccination.

The next question sought if the respondent was vaccinated against HPV. If yes, we asked about the recommending individual and the reasons why she chose to get vaccinated. If no, we asked why she chose not to get vaccinated. Lastly, we asked if the respondent would recommend vaccination to her female friends.

The obtained data were processed using Microsoft Excel and statistically analyzed. The data were analyzed with Medcalc version 24 (IBM, Armonk, NY, USA). Pearson $\chi^{2}$ and Fisher exact tests were used to assess the differences, and $p<0.05$ was considered statistically significant. Continuous data were analyzed with Student's t-test.

The binary logistic regression was used to specify which observed parameters statistically significantly influenced the HPV vaccination rate. The separate model was created for both the Czech and Slovak Republics. Parameters included in both models were: age, number of siblings, how was the information about possibility of HPV vaccination obtained, attending regular preventive gynaecological check-ups, the population of the city of residence, if a physician provided information about the possibility of HPV vaccination, active practice of religion, a parent as a medical professional, and severe cervical disease among relatives and friends. The significance level was $\alpha=0.05$. The statistical software IBM SPSS 19 was used to generate the binary logistic regression.

The study was approved by the Ethical Committee of the Faculty of Medicine, Comenius University, Bratislava on 10 April 2018.

\section{RESULTS}

We obtained 684 questionnaires from the Czech Republic; 43 were excluded due to different nationality (Slovak students studying in the Czech Republic), and 11 were excluded because they were filled by students different course (students of stomatology). The final number of Czech questionnaires was 630 .

We obtained 795 questionnaires from the Slovak Republic; 16 were excluded because they were filled by students of different courses, and two were excluded due to different nationality. The final number of Slovak questionnaires was 776. Figure 1 shows the distribution of female medical students from individual medical faculties from the Czech and Slovak Republics.

Table 1 compares some demographic parameters between Slovak and Czech students. Table 2 summarizes the factors influencing the rate of vaccination of female medical students in both countries.

For the question stated "who recommended the HPV vaccination to the vaccinated students", 37 (22.6\%) Slovak students and 51 (12.4\%) Czech students stated "a gynaecologist", 53 (32.3\%) Slovak students and 148 (35.9\%) Czech students stated "a paediatrician”, 66 (40.2\%) Slovak students and 20 (49.0\%) Czech students stated "parents" and 8 (4.9\%) Slovak students and 11 (2.7\%) Czech students stated "other person".

When residency was considered in the Slovak Republic, in communities with less than 5,000 inhabitants, 51 out of 251 $(20.3 \%)$ female medical students were informed by a paediatrician. In communities with above 100,000 inhabitants, 51 out of $157(32.5 \%)$ female medical students were informed by a paediatrician, $\mathrm{OR}=0.53,95 \% \mathrm{CI}: 0.34-0.83, \mathrm{p}=0.006$. In the Czech Republic, in communities with less than 5,000 inhabitants, 108 out of 195 (55.4\%) female medical students were informed by a paediatrician. In communities with above 100,000 inhabitants, 85 out of $156(54.5 \%)$ students were informed by a paediatrician. The difference was not statistically significant $(\mathrm{p}=0.867)$.

Figure 2 summarizes the main sources of information about vaccination from both countries. 


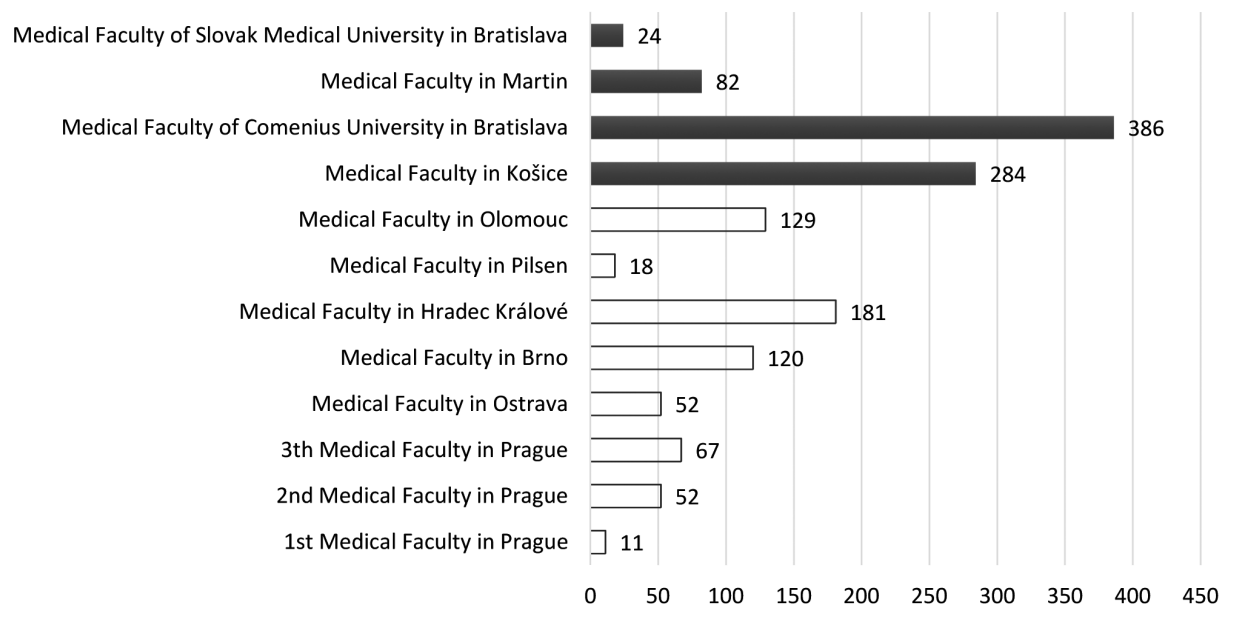

Fig. 1. Distribution of respondents from individual medical faculties from the Czech (white) and Slovak (black) Republics.

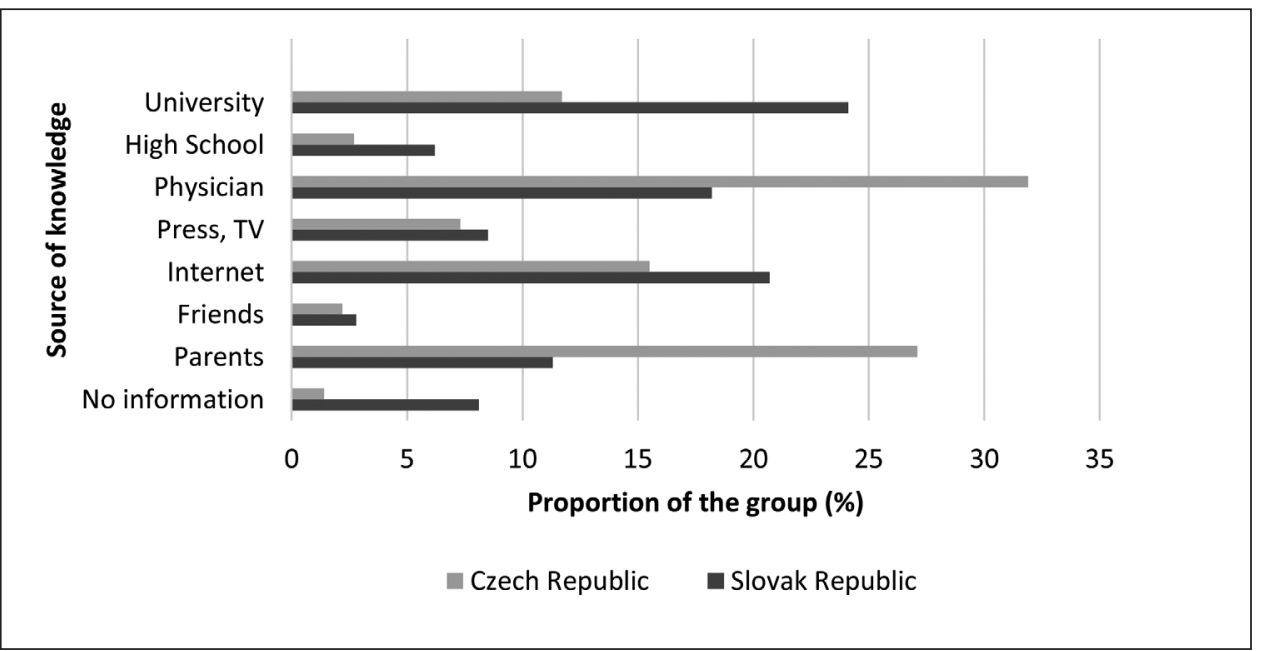

Fig. 2. Sources of information about vaccination.

Table 1. Demographic characteristics of respondents in both countries

\begin{tabular}{|c|c|c|c|c|c|}
\hline & \multicolumn{2}{|c|}{ Czech Republic ( $n=630)$} & \multicolumn{2}{|c|}{ Slovak Republic $(n=776)$} & \multirow{2}{*}{ p-value } \\
\hline & $\mathrm{n}$ & $\%$ & $\mathrm{n}$ & $\%$ & \\
\hline Average age (years) & $22.9(19-28)$ & & $22.4(19-36)$ & & $<0.001$ \\
\hline \multicolumn{6}{|c|}{ Number of inhabitants in the community where respondent grew up } \\
\hline Under 5,000 & 195 & 30.9 & 251 & 32.3 & 0.604 \\
\hline $5,000-99,999$ & 279 & 44.3 & 368 & 47.4 & 0.259 \\
\hline 100,000 and more & 156 & 24.8 & 157 & 20.2 & 0.046 \\
\hline \multicolumn{6}{|l|}{ Religion } \\
\hline Catholic & 88 & 14.0 & 437 & 56.3 & $<0.001$ \\
\hline Protestant & 8 & 1.3 & 27 & 3.5 & 0.009 \\
\hline Other & 2 & 0.3 & 0 & & \\
\hline None & 532 & 84.4 & 312 & 40.2 & $<0.001$ \\
\hline Average number of siblings & 1.3 & & 1.4 & & 0.070 \\
\hline Only child & 68 & 10.8 & 101 & 13.0 & 0.216 \\
\hline Three siblings and more & 52 & 8.3 & 82 & 10.6 & 0.145 \\
\hline Parent as medical professional & 174 & 27.6 & 177 & 22.8 & 0.041 \\
\hline Severe cervical disease in relatives or friends & 101 & 16.0 & 88 & 11.3 & 0.012 \\
\hline
\end{tabular}


Table 2. Vaccination against HPV and factors influencing the rate of vaccination in both countries

\begin{tabular}{|c|c|c|c|c|c|}
\hline & \multicolumn{2}{|c|}{ Czech Republic ( $n=630)$} & \multicolumn{2}{|c|}{ Slovak Republic $(n=776)$} & \multirow{2}{*}{ p-value } \\
\hline & $\mathrm{n}$ & $\%$ & $\mathrm{n}$ & $\%$ & \\
\hline Have you ever attended a gynaecological check-up? & 601 & 95.4 & 664 & 85.6 & $<0.001$ \\
\hline Do you regularly attend a gynaecological oncological screening? & 477 & 75.7 & 448 & 57.7 & $<0.001$ \\
\hline Have you been informed about the HPV vaccination by your gynaecologist? & 156 & 26.0 & 195 & 29.4 & 0.187 \\
\hline Have you been informed about the HPV vaccination by your paediatrician? & 351 & 55.7 & 209 & 26.9 & $<0.001$ \\
\hline Was completely vaccinated against HPV & 412 & 65.4 & 164 & 21.1 & $<0.001$ \\
\hline Would you recommend the vaccination to your relatives or friends? & 545 & 86.5 & 625 & 80.5 & 0.003 \\
\hline
\end{tabular}

Table 3. Convincing factors to get vaccinated

\begin{tabular}{|l|c|c|c|c|}
\hline \multirow{2}{*}{} & \multicolumn{2}{|c|}{ Czech Republic $(\mathrm{n}=\mathbf{4 1 2}$} & \multicolumn{2}{c|}{ Slovak Republic $(\mathrm{n}=164)$} \\
\cline { 2 - 5 } & $\mathrm{n}$ & $\%$ & $\mathrm{n}$ & $\%$ \\
\hline Fear of cervical disease & 253 & 61.4 & 98 & 59.8 \\
\hline My surroundings convinced me & 124 & 30.1 & 39 & 23.8 \\
\hline Physician convinced me & 28 & 6.8 & 18 & 11.0 \\
\hline Other reason & 7 & 1.7 & 9 & 5.5 \\
\hline
\end{tabular}

Table 4. Why respondents did not get vaccinated

\begin{tabular}{|c|c|c|c|c|}
\hline & \multicolumn{2}{|c|}{ Czech Republic ( $n=218)$} & \multicolumn{2}{|c|}{ Slovak Republic $(n=612)$} \\
\hline & $\mathrm{n}$ & $\%$ & $\mathrm{n}$ & $\%$ \\
\hline My risk of infection is low & 74 & 33.9 & 186 & 30.4 \\
\hline Not informed about possibility of vaccination & 36 & 16.5 & 176 & 28.8 \\
\hline Price & 57 & 26.1 & 116 & 19.0 \\
\hline Fear of side effects & 22 & 10.1 & 43 & 7.0 \\
\hline Cytological screening is enough & 11 & 5.0 & 26 & 4.2 \\
\hline Other reason & 18 & 8.3 & 65 & 10.6 \\
\hline
\end{tabular}

Table 3 summarizes the reasons for receiving vaccination as stated by vaccinated students in both countries.

Table 4 shows the reasons for refusing vaccination as stated by unvaccinated students in both countries.

Tables $5 \mathrm{a}$ and $5 \mathrm{~b}$ compares some factors that influenced students in both countries.

Tables $6 \mathrm{a}$ and $6 \mathrm{~b}$ compares the source of information in vaccinated and unvaccinated students in both countries.

In the Czech Republic, the source of information about vaccination was stated by 621 students $(98.6 \%)$. Out of those, 542 $(87.3 \%)$ students would recommend vaccination to their family and friends. Out of 9 students who stated that they did not obtain any information about vaccination, $3(33.3 \%)$ would recommend vaccination, $\mathrm{OR}=13.72,95 \% \mathrm{CI}: 3.36-56.00, \mathrm{p}<0.001$.

In the Slovak Republic, the source of information about vaccination was stated by 713 students $(91.9 \%)$. Out of those, 584 $(81.9 \%)$ students would recommend vaccination to their family and friends. Out of 63 students who stated that they did not obtain any information about vaccination, 41 (65.1\%) would recommend vaccination, $\mathrm{OR}=2.43,95 \% \mathrm{CI}: 1.40-4.22, \mathrm{p}=0.002$.

Since 2007, vaccination has been available in the Czech Republic. Since 2012, vaccination has been covered by public health insurance for 13-year-old girls. In the Slovak Republic, vaccination has been covered by public health insurance for girls between 12 and 13 years since 2019. In our study conducted in 2018, Czech girls who were 19 years old could get vaccinated and the cost would be paid by public health insurance. This group accounted for 24 students (3.8\%), of which 20 were vaccinated $(83.3 \%)$. Among older students, 392 out of $606(64.7 \%)$ were vaccinated. The difference is statistically insignificant $(\mathrm{p}=0.070)$.

\section{Results Obtained by Binary Logistic Regression}

For the Czech Republic model, following parameters statistically significantly influenced the rate of HPV vaccination: age $(p=0.002)$, number of siblings $(p=0.009)$, the source of information about HPV vaccination $(\mathrm{p}<0.001)$ and the type of specialist providing information $(\mathrm{p}<0.001)$. The probability of vaccination was increased by higher age of respondent $(\mathrm{OR}=1.19,95 \% \mathrm{CI}$ : $1.06-1.33)$, decreased by higher number of siblings $(\mathrm{OR}=0.75$, 95\% CI: $0.60-0.93)$, increased by information obtained from friends and modern media $(\mathrm{OR}=2.14,95 \% \mathrm{CI}: 1.230-3.70)$ and increased by information provided by a treating physician $(\mathrm{OR}=7.22,95 \% \mathrm{CI}: 4.14-12.59)$. Comparing to other sources 
Table 5a. Comparison of the influence of some factors on vaccination rate in the Czech Republic

\begin{tabular}{|c|c|c|c|}
\hline & \multicolumn{2}{|c|}{ Czech Republic } & \multirow{3}{*}{$\mathrm{p}$-value } \\
\hline & Vaccinated $(n=412)$ & Not vaccinated $(n=218)$ & \\
\hline & $\mathrm{n}(\%)$ & $\mathrm{n}(\%)$ & \\
\hline Average age (years) & 22.8 & 22.9 & 0.549 \\
\hline \multicolumn{4}{|c|}{ Number of inhabitants in the community where respondent grew up } \\
\hline Under 5,000 & $128(65.6)$ & $67(34.3)$ & 0.931 \\
\hline $5,000-99,999$ & $181(64.9)$ & $98(35.1)$ & 0.806 \\
\hline 100,000 and more & $103(66.0)$ & $53(34.0)$ & 0.849 \\
\hline \multicolumn{4}{|l|}{ Religion } \\
\hline Catholic & $52(59.1)$ & $36(40.9)$ & 0.193 \\
\hline Protestant & $4(50.0)$ & $4(50.0)$ & \\
\hline Others & $1(50.0)$ & $1(50.0)$ & \\
\hline None & $355(66.7)$ & $177(33.3)$ & 0.111 \\
\hline Average number of siblings & 1.24 & 1.44 & 0.007 \\
\hline Only child & $46(67.6)$ & $22(32.4)$ & 0.680 \\
\hline Three siblings and more & $26(50.0)$ & $26(50.0)$ & $\begin{array}{c}0.016 \\
\mathrm{OR}=0.50(95 \% \mathrm{Cl}: 0.28-0.88)\end{array}$ \\
\hline Parent as a medical professional & $133(76.4)$ & $41(23.6)$ & $\begin{array}{c}<0.001 \\
\mathrm{OR}=2.06(95 \% \mathrm{Cl}: 1.38-3.06)\end{array}$ \\
\hline Severe cervical disease in relatives or friends & $75(74.3)$ & $26(25.7)$ & $\begin{array}{c}0.042 \\
\mathrm{OR}=1.64(95 \% \mathrm{Cl}: 1.02-2.66)\end{array}$ \\
\hline Regularly attend gynaecological oncological screening & $321(67.3)$ & $156(32.7)$ & 0.078 \\
\hline Informed about vaccination by gynaecologist & $89(57.0)$ & $67(43.0)$ & $\begin{array}{c}0.006 \\
\mathrm{OR}=0.59(95 \% \mathrm{Cl}: 0.41-0.86)\end{array}$ \\
\hline Informed about vaccination by paediatrician & $281(80.0)$ & $70(19.9)$ & $\begin{array}{c}<0.001 \\
\mathrm{OR}=4.53(95 \% \mathrm{Cl}: 3.19-6.45)\end{array}$ \\
\hline $\begin{array}{l}\text { Would recommend vaccination to their relatives and } \\
\text { friends }\end{array}$ & $398(73.0)$ & $147(27.0)$ & $\begin{array}{c}<0.001 \\
\mathrm{OR}=13.73(95 \% \mathrm{Cl}: 7.51-25.11)\end{array}$ \\
\hline
\end{tabular}

of information, the most influencing was information obtained from parents $(\mathrm{OR}=17.98,95 \% \mathrm{CI}$ : 9.47-34.17). The information obtained from treating paediatrician increased the probability of vaccination compared to unvaccinated students $(\mathrm{OR}=5.08,95 \%$ CI: 2.90-3.07).

For the Slovak Republic model, following parameters statistically significantly influenced the rate of HPV vaccination: age $(p=0.003)$, active practice of religion $(p=0.001)$, physician as a source of information $(p<0.001)$, severe cervical disease among relatives and friends $(p=0.010)$ and the source of information ( $p$ $<0.001$ ). The probability of vaccination was increased by higher age $(\mathrm{OR}=1.16,95 \% \mathrm{CI}: 1.05-1.29)$ and not practicing any religion $(\mathrm{OR}=2.08,95 \% \mathrm{CI}: 1.34-3.21)$. Information provided by gynaecologist increased the probability of vaccination compared to those not obtaining information from any physician $(\mathrm{OR}=2.56$, $95 \%$ CI: $1.35-4.86)$. Information provided by paediatrician/adolescent health specialists increased the probability of vaccination even more compared to those not obtaining information from any physician $(\mathrm{OR}=5.28,95 \% \mathrm{CI}: 2.81-9.90)$. Severe cervical disease among relatives and friends increased the probability of vaccination $(\mathrm{OR}=2.27,95 \% \mathrm{CI}: 1.22-4.21)$. Information provided by treating physician increased the probability comparing to other respondents $(\mathrm{OR}=8.91,95 \% \mathrm{CI}$ : 4.62-17.20). The infor- mation provided by parents was the most influencing parameter $(\mathrm{OR}=19.13$, 95\% CI: 9.50-38.62)

\section{DISCUSSION}

The respondents in the Czech Republic were older students (their average age was 22.9 years compared with 22.4 years for the Slovak Republic), but this fact was insignificant since we did not find statistical reliance between the rate of vaccination and age of respondents in both countries. As stated in Table 3, the average age of vaccinated students in the Czech Republic was 22.8 years and the average age of unvaccinated students was 22.9 years. The age distribution was not statistically significant $(p=0.549)$. Similarly, in the Slovak population, the average age of vaccinated students was 22.6 years and of unvaccinated students 22.3 years. The age distribution in both groups was not statistically significant $(\mathrm{p}=0.117)$.

We did not find any important difference in the rate of vaccination regarding the size of communities in both countries. Among Czech students, $14 \%$ were Catholics and $84.4 \%$ were atheists. In 2011, $10.4 \%$ of inhabitants were Catholics and $44.7 \%$ were atheist (11). Among Slovak students, 56.3\% were Catholics and 
Table 5b. Comparison of the influence of some factors on vaccination rate in the Slovak Republic

\begin{tabular}{|c|c|c|c|}
\hline & \multicolumn{2}{|c|}{ Slovak Republic } & \multirow{3}{*}{$\mathrm{p}$-value } \\
\hline & Vaccinated $(n=164)$ & Not vaccinated $(n=612)$ & \\
\hline & $\mathrm{n}(\%)$ & $\mathrm{n}(\%)$ & \\
\hline Average age (years) & 22.6 & 22.3 & 0.117 \\
\hline \multicolumn{4}{|c|}{ Number of inhabitants in the community where respondent grew up } \\
\hline Under 5,000 & $38(15.1)$ & $213(84.9)$ & $\begin{array}{c}0.005 \\
\mathrm{OR}=0.56(95 \% \mathrm{Cl}: 0.38-0.84)\end{array}$ \\
\hline $5,000-99,999$ & $86(23.4)$ & $282(76.6)$ & 0.148 \\
\hline 100,000 and more & $40(25.5)$ & $117(74.5)$ & 0.136 \\
\hline \multicolumn{4}{|l|}{ Religion } \\
\hline Catholic & $63(14.4)$ & $374(85.6)$ & $\begin{array}{c}<0.001 \\
\mathrm{OR}=0.40(95 \% \mathrm{Cl}: 0.28-0.57)\end{array}$ \\
\hline Protestant & $7(25.9)$ & $20(74.1)$ & 0.536 \\
\hline \multicolumn{4}{|l|}{ Others } \\
\hline None & $94(30.1)$ & $218(69.9)$ & $\begin{array}{c}<0.001 \\
\mathrm{OR}=2.43(95 \% \mathrm{Cl}: 1.71-3.45)\end{array}$ \\
\hline Average number of siblings & 1.31 & 1.42 & 0.293 \\
\hline Only child & $23(22.8)$ & 78 (77.2) & 0.666 \\
\hline Three siblings and more & $19(23.2)$ & $63(76.8)$ & 0.633 \\
\hline Parent as a medical professional & $57(32.2)$ & $120(67.8)$ & $\begin{array}{c}<0.001 \\
\mathrm{OR}=2.18(95 \% \mathrm{Cl}: 1.50-3.19)\end{array}$ \\
\hline Severe cervical disease in relatives or friends & $28(31.8)$ & $60(68.2)$ & $\begin{array}{c}0.010 \\
\mathrm{OR}=1.89(95 \% \mathrm{Cl}: 1.16-3.08)\end{array}$ \\
\hline Regularly attending gynaecological oncological screening & $118(26.3)$ & $330(73.7)$ & $\begin{array}{c}<0.001 \\
\mathrm{OR}=2.19(95 \% \mathrm{Cl}: 1.50-3.19)\end{array}$ \\
\hline Informed about vaccination by gynaecologist & $46(23.6)$ & $149(76.4)$ & 0.737 \\
\hline Informed about vaccination by paediatrician & $94(45.0)$ & $115(55.0)$ & $\begin{array}{c}<0.001 \\
\mathrm{OR}=5.80(95 \% \mathrm{Cl}: 4.00-8.40)\end{array}$ \\
\hline $\begin{array}{l}\text { Would recommend vaccination to their relatives and } \\
\text { friends }\end{array}$ & $161(25.8)$ & $464(74.2)$ & $\begin{array}{c}<0.001 \\
\mathrm{OR}=17.11(95 \% \mathrm{Cl}: 5.38-54.4)\end{array}$ \\
\hline
\end{tabular}

$40.2 \%$ were atheists. In $2011,62 \%$ of inhabitants were Catholics and $13.4 \%$ were atheists. Compared with 2001 , there was a $9 \%$ decrease in Catholicism and a 4\% increase in atheism (12).

The number of students having a medical professional as a parent in the Czech Republic was $27.6 \%$ and $22.8 \%$ in the Slovak Republic. The difference was statistically significant. In a questionnaire-based study conducted in the USA involving medical students, $22 \%$ of respondents indicated having a medical professional as a parent (13). Since having a medical professional as a parent raises the probability of getting vaccinated, their higher number in the Czech Republic probably caused the higher rate of vaccination. We did not observe a statistically significant difference regarding the average number of siblings, number of only child and bigger families (four children and more). The higher occurrence of severe diseases among close family members and friends in the Czech Republic (16.0\%) increased the rate of vaccination compared with the Slovak Republic (11.3\%). In a questionnaire-based study conducted in Texas involving opinions about HPV vaccination, the prevalence of cervical disease in the respondent's relatives was $17 \%$ but did not play a significant role in accepting vaccination (14). A significant difference was also found regarding attendance of regular cervical screening. In the Czech Republic, regular attendance of cervical screening was reported by $75.7 \%$ of respondents and $57.7 \%$ for the Slovak Republic. Better organization and more frequent participation in cervical screening are also linked with lower lifelong risk of invasive cervical carcinoma. In the Czech Republic, the risk is $1.3 \%$, and in the Slovak Republic 1.6\% (15).

The most important factor that positively influenced vaccination rate in the Czech Republic was the information obtained from respondent's paediatrician. In the Czech Republic, 55.7\% of respondents were informed by a paediatrician about the possibility of vaccination. In the Slovak Republic, it was only $26.9 \%$.

Conducting a study on factors influencing Slovak paediatrician's attitude towards HPV vaccination would be very beneficial to discover why their recommendation is so low. One of such factors might be their higher age. In 2017, their average age was 59 years, and $56.4 \%$ were above 60 years (16). Physicians under 49 years of age more often recommend vaccination against HPV than physicians above 50 years $(\mathrm{OR}=1.8)(17)$.

A very interesting factor was the size of the community where the respondent grew up. In the Czech Republic, the community 
Table 6a. Main source of information about HPV vaccination in the Czech Republic

\begin{tabular}{|c|c|c|c|}
\hline \multirow{3}{*}{ Main source of information } & \multicolumn{2}{|c|}{ Czech Republic } & \multirow{3}{*}{$p$-value } \\
\hline & Vaccinated $(n=412)$ & Not vaccinated $(n=218)$ & \\
\hline & $\mathrm{n}(\%)$ & $\mathrm{n}(\%)$ & \\
\hline University & $22(29.7)$ & $52(70.3)$ & $\begin{array}{c}<0.001 \\
\mathrm{OR}=0.18(95 \% \mathrm{Cl}: 0.11-0.31)\end{array}$ \\
\hline High School & $6(35.3)$ & $11(64.7)$ & $\begin{array}{c}0.013 \\
\mathrm{OR}=0.28(95 \% \mathrm{Cl}: 0.10-0.76)\end{array}$ \\
\hline Physician & $163(81.1)$ & $38(18.9)$ & $\begin{array}{c}<0.001 \\
\mathrm{OR}=3.10(95 \% \mathrm{Cl}: 2.07-4.63)\end{array}$ \\
\hline Press, television, radio & $17(37.0)$ & $29(63.0)$ & $\begin{array}{c}<0.001 \\
\mathrm{OR}=0.28(95 \% \text { Cl: } 0.15-0.52)\end{array}$ \\
\hline Internet & $45(45.9)$ & $53(54.1)$ & $\begin{array}{c}<0.001 \\
\mathrm{OR}=0.38(95 \% \text { Cl: } 0.25-0.59)\end{array}$ \\
\hline Friends & $6(42.8)$ & $8(57.1)$ & 0.083 \\
\hline Parents & $152(88.9)$ & $19(11.1)$ & $\begin{array}{c}<0.001 \\
\mathrm{OR}=6.12(95 \% \mathrm{Cl}: 3.67-10.2)\end{array}$ \\
\hline No knowledge & $1(11.1)$ & $8(88.9)$ & $\begin{array}{c}0.010 \\
\mathrm{OR}=0.06(95 \% \mathrm{Cl}: 0.01-0.51)\end{array}$ \\
\hline
\end{tabular}

Table 6b. Main source of information about HPV vaccination in the Slovak republic

\begin{tabular}{|c|c|c|c|}
\hline \multirow{3}{*}{ Main source of information } & \multicolumn{2}{|c|}{ Slovak Republic } & \multirow{3}{*}{$p$-value } \\
\hline & Vaccinated $(n=164)$ & Not vaccinated $(n=612)$ & \\
\hline & $n(\%)$ & $\mathrm{n}(\%)$ & \\
\hline University & $11(5.9)$ & $176(94.1)$ & $\begin{array}{c}<0.001 \\
\mathrm{OR}=0.18(95 \% \mathrm{Cl}: 0.09-0.34)\end{array}$ \\
\hline High School & $3(6.2)$ & $45(93.8)$ & $\begin{array}{c}0.016 \\
\mathrm{OR}=0.23(95 \% \mathrm{Cl}: 0.07-0.77)\end{array}$ \\
\hline Physician & $70(49.6)$ & $71(50.4)$ & $\begin{array}{c}<0.001 \\
\mathrm{OR}=5.67(95 \% \mathrm{Cl}: 3.82-8.43)\end{array}$ \\
\hline Press, television, radio & $7(10.6)$ & $59(89.4)$ & $\begin{array}{c}0.033 \\
\text { OR: } 0.42 \text { (95\% Cl: } 0.19-0.93)\end{array}$ \\
\hline Internet & $16(9.9)$ & $146(90.1)$ & $\begin{array}{c}<0.001 \\
\mathrm{OR}=0.35(95 \% \mathrm{Cl}: 0.20-0.60)\end{array}$ \\
\hline Friends & $1(4.5)$ & $21(95.5)$ & 0.087 \\
\hline Parents & $53(60.9)$ & $34(39.1)$ & $\begin{array}{c}<0.001 \\
\mathrm{OR}=8.12(95 \% \mathrm{Cl}: 5.04-13.07)\end{array}$ \\
\hline No knowledge & $1(1.6)$ & $60(98.4)$ & $\begin{array}{c}0.004 \\
\mathrm{OR}=0.06(95 \% \mathrm{Cl}: 0.01-0.41)\end{array}$ \\
\hline
\end{tabular}

size did not affect the rate of vaccination. In the Slovak Republic, respondents from communities with less than 5,000 inhabitants had a significantly lower chance of vaccination. It is probably related to the substantial religiosity and strongly conservative thinking of parents and paediatricians in those regions. In our study, Slovak students who came from communities with less than 5,000 inhabitants were informed by a paediatrician in $20.3 \%$ of cases. In communities with above 100,000 inhabitants, they were informed in $32.5 \%$ of cases $(\mathrm{OR}=0.53,95 \% \mathrm{CI}$ : $0.34-0.83$, $\mathrm{p}=0.006)$. Czech students who came from communities with less than 5,000 inhabitants were informed by a paediatrician in $55.4 \%$ of cases. In the communities with above 100,000 inhabitants, they were informed in $45.5 \%$ of cases. The difference was not statistically significant $(\mathrm{p}=0.867)$.

Another strong factor of not being vaccinated in the Slovak Republic was Catholicism. In the Czech Republic, the role of Catholicism was not statistically significant. Unfortunately, online pro-life and ultra-conservative websites in the Slovak Republic conduct a strong campaign against HPV vaccination because vaccination "supports promiscuity". They believe that the best prevention is fidelity between partners $(18,19)$. In an online gynaecological advisory for catholic couples, a gynaecologist, Dr. Wallenfels, clearly dissuades girls from getting vaccinated against HPV (20). The protestant religion did not significantly affect the 
vaccination rate in the Slovak Republic, not even when compared with respondents with no religion $(25.9 \%$ vs. $30.1 \%, p=0.415)$.

The belief of low personal risk of getting infected was stated as a reason for not getting vaccinated most often in both countries. In the Slovak Republic, it was stated by $30.4 \%$ of unvaccinated respondents and in the Czech Republic by $33.9 \%$ of them. The second most common reason for not getting vaccinated was high cost in the Czech Republic (26.1\%) and not being informed in the Slovak Republic (28.8\%).

The problem of high cost was solved by including HPV vaccination among treatments covered by public health insurance. Since then, the most important role of medical professionals, governmental bodies and non-governmental institutions is to inform lay and professional communities about the risk of HPV infection and the benefits of vaccination. The most important factor that increases the rate of vaccination is obtaining information from a paediatrician. In the Czech Republic, this factor increased the probability of getting vaccinated with $\mathrm{OR}=3.10(95 \% \mathrm{CI}$ : 2.07-4.63, $\mathrm{p}<0.001)$ and in the Slovak Republic with $\mathrm{OR}=5.67$ (95\% CI: 3.82-8.43, $\mathrm{p}<0.001)$. Medical professional was stated as the strongest motivator for getting vaccinated by several large studies $(21,22)$.

In the Czech Republic, having a medical professional as a parent increased the probability of getting vaccinated with $\mathrm{OR}=2.06$ (95\% CI: 1.39-3.06) and in the Slovak Republic with $\mathrm{OR}=2.18$ (95\% CI: 1.50-3.19). Up till now, no study evaluating this fact has been published. The connection between the level of education of parents and vaccination of their daughters is unclear. Some studies did not show connection (23), while others confirmed higher vaccination in children of parents with academic education (24). Other studies showed higher vaccination in children of parents with high school education compared with college (25).

Insufficient knowledge about HPV infection and its consequences increased the risk of rejection of vaccination by parents of adolescent girls with $\mathrm{OR}=3.7$ (26). It can be assumed that medical education of parents is connected with higher awareness of HPV infection, the effect of vaccination and its potentially adverse effects, which can lead to higher adherence to vaccination.

Severe cervical disease among relatives and friends increased the rate of vaccination in the Czech Republic with $\mathrm{OR}=1.64$ (95\% CI: 1.02-2.66, p=0.042) and in the Slovak Republic with $\mathrm{OR}=1.89(95 \% \mathrm{CI}: 1.16-3.08, \mathrm{p}=0.010)$. Fear of disease as the main reason to get vaccinated was stated by $61.4 \%$ of vaccinated respondents in the Czech Republic and $59.8 \%$ of vaccinated respondents in the Slovak Republic. The occurrence of disease among relatives and friends increases this fear for sure.

The intention to get their daughter vaccinated against HPV is present more often in mothers who were treated for cervical carcinoma with $\mathrm{OR}=3.19$, mothers with benign hysterectomy in their history with $\mathrm{OR}=3.15$, and mothers who were treated for cervical dysplasia with $\mathrm{OR}=3.05$. Pathological cytological screening without any treatment in a mother did not increase her willingness to get her daughter vaccinated (27).

Those who would recommend vaccination to their relatives and friends amounts to $86.5 \%$ in the Czech Republic and $80.5 \%$ in the Slovak Republic $(\mathrm{p}=0.003)$. The most important factor was being informed, which increased the probability of vaccination in the Czech Republic with OR=13.72 and in the Slovak Republic with $\mathrm{OR}=2.43$. Self-application increased the probability of vaccina- tion recommendation in the Czech Republic with $\mathrm{OR}=13.73$ and in the Slovak Republic with $\mathrm{OR}=17.11$. A questionnaire-based study conducted among medical students in China (473 girls and 549 boys) showed similar results; $92.6 \%$ of girls and $91.6 \%$ of boys would recommend vaccination to their future patients. The knowledge of HPV vaccination increased the chance of getting vaccinated in girls with $\mathrm{OR}=1.41$ and in boys with $\mathrm{OR}=1.51$. Vaccinated girls would recommend vaccination more often with $\mathrm{OR}=15.84$ (28).

The limitation of this study is the internet-based form of questionnaires. Controlled interview would be more precise in data collection. This limitation is compensated by the robustness of the observed population. Majority of studies mentioned above provide data acquired through internet survey, which is considered to be the standardized method of obtaining subjective data.

\section{CONCLUSION}

The prevalence of invasive oncological cervical diseases is lower in the Czech Republic than in the Slovak Republic. The most important reason is probably the effectively established oncologic programme with organized oncologic screening and much higher participation of women in cervical screening programme. In our study, we proved that female medical students from Czech medical faculties regularly attend preventive gynaecological check-ups more often. The vaccine was registered in both countries at a similar time in the same year. On the other hand, the vaccine was covered by public health insurance in 2012 in the Czech Republic and in 2019 in the Slovak Republic. Most respondents in our study had to pay for the vaccine on their own in both countries. Despite that, the vaccination rate is significantly higher in the Czech Republic. The important reason is that Czech students were more often informed about vaccination by their paediatricians. Some of the reasons for the lower vaccination rate in the Slovak Republic are substantial conservatism, girls growing up in smaller communities and Catholicism. Slovak students also indicated lower rate of received information about vaccination. Slovak students recommend the vaccination to their relatives and friends less often than Czech students.

\section{Acknowledgements}

The authors thank all the members of medical student associations who cooperated in data collection.

\section{Conflict of Interests}

None declared

\section{Funding}

This work was supported by the University Hospital in Hradec Králové (a long-term organization development plan).

\section{REFERENCES}

1. Institute of Health Information and Statistics of the Czech Republic. Cancer incidence in the Czech Republic, 2016 [Internet]. Prague: IHIS CR [cited 2019 Aug 26]. Available from: https://www.uzis.cz/sites/default/ files/knihovna/novotvary2016.pdf. (In English, Czech.) 
2. National Health Information Center. Cancer incidence in the Slovak Republic 2011 [Internet]. Bratislava: NHIC; 2018 [cited 2019 Aug 26]. Available from: http://data.nczisk.sk/statisticke_vystupy/Onkologia/ incidencia_zhubnych_nadorov_2011.pdf. (In English, Slovak)

3. Institute of Health Information and Statistics of the Czech Republic. Incidence of malignant neoplasms in the Czech Republic in 2011. Topical information 25 [Internet]. Prague: IHIS CR; 2014 [cited 2019 Aug 26]. Available from: https://www.uzis.cz/sites/default/files/knihovna/ ai_2014_25.pdf. (In Czech.)

4. Voidăzan S, Tarcea M, Morariu S-H, Grigore A, Dobreanu M. Human Papillomavirus vaccine - knowledge and attitudes among parents of children aged 10-14 years: a cross-sectional study, Tîrgu Mureş, Romania. Cent Eur J Public Health. 2016;24(1):29-38.

5. Lenselink CH, Gerrits MMJG, Melchers WJG, Massuger LFAG, van Hamont D, Bekkers RLM. Parental acceptance of Human Papillomavirus vaccines. Eur J Obstet Gynecol Reprod Biol. 2008;137(1):103-7.

6. Petrosky E, Bocchini JA, Hariri S, Chesson H, Curtis CR, Saraiya M, et al. Use of 9-valent human papillomavirus (HPV) vaccine: updated HPV vaccination recommendations of the advisory committee on immunization practices. MMWR Morb Mortal Wkly Rep. 2015;64(11):300-4.

7. Sehnal B, Vojáčková N, Driák D, Kmoníčková E, Vaňousová D, Maxová $\mathrm{K}$, et al. Anticipated efficacy of HPV vaccination in prophylaxis against nongenital cancers. Klin Onkol. 2014;27(4):239-46. (In Czech.)

8. Ministry of Health of Slovak Republic. The government approved the national oncological program [Internet]. Bratislava: MZ SR; 2018 [cited 2019 Aug 26]. Available from: https://www.health.gov.sk/Clanok?vladaschvalila-narodny-onkologicky-program. (In Slovak.)

9. Czech Society for Oncology. The national oncological program [Internet]. Prague: CSO; 2013 [cited 2019 Aug 26]. Available from: https://www. linkos.cz/narodni-onkologicky-program/text-narodniho-onkologickehoprogramu/. (In Czech.)

10. Poljak M, Seme K, Maver PJ, Kocjan BJ, Cuschieri KS, Rogovskaya SI, et al. Human Papillomavirus prevalence and type-distribution, cervical cancer screening practices and current status of vaccination implementation in Central and Eastern Europe. Vaccine. 2013;31 Suppl 7:H59-70.

11. Czech Statistical Office. Czech demographic handbook - 2014 [Internet]. Prague: CSO; 2015 [cited 2019 Aug 26]. Available from: https://www. czso.cz/csu/czso/czech-demographic-handbook-2014.

12. Statistical Office of the Slovak Republic. Census of residents, homes, and flats in 2011 [Internet]. Bratislava: Statistical Office of the SR [cited 2019 Aug 26]. Available from: https://archiv.statistics.sk/open_data/data/ sodb_2011/. (In Slovak.)

13. Choi KJ, Tak HJ, Bach C, Trias C, Warsi H, Abraham J, et al. Characteristics of medical students with physician relatives: a national study. MedEdPublish. 2018;7(1):30. doi: 10.15694/mep.2018.0000030.1.

14. Rosenthal SL, Rupp R, Zimet GD, Meza HM, Loza ML, Short MB, et al. Uptake of HPV vaccine: demographics, sexual history and values, parenting style, and vaccine attitudes. J Adolesc Health. 2008;43(3):239-45.

15. Ondrusova $\mathrm{M}$, Zubor $\mathrm{P}$, Ondrus $\mathrm{D}$. Time trends in cervical cancer epidemiology in the Slovak Republic: reflection on the non-implementation of screening with international comparisons. Neoplasma. 2012;59(2):121-8.

16. Nagyova Z, Kostalova Z, Prokopova E. Primary pediatrics [Internet]. Bratislava: MZ SK [cited 2019 Aug 26]. Available from: https://www.
health.gov.sk/Sources/dokumenty/IZP/priloha5-rs-201901.ppt. (In Slovak.)

17. Vadaparampil ST, Kahn JA, Salmon D, Lee J-H, Quinn GP, Roetzheim $\mathrm{R}$, et al. Missed clinical opportunities: provider recommendations for HPV vaccination for 11-12 year old girls are limited. Vaccine. 2011;29(47):8634-41.

18. LifeNews Slovakia. Vaccination against uterine cervix cancer causes death [Internet]. LifeNews Slovakia; 2015 [cited 2019 Aug 30]. Available from: http://www.lifenews.sk/8136/vakcina-proti-rakovine-krcka-maternicesposobuje-smrt. (In Slovak.)

19. Höppner O. An instructive incident of one struggle against a fatal disease. How to protect oneself against HPV? How to go against uterine cervix carcinoma? A prescription from the times of a natural world. Shall we take it into account? [Internet]. PROTIPRÚD; 2015 [cited 2019 Aug 30]. Available from: http://ppsk.aplikace.net/zdravie/1708.htm. (In Slovak.)

20. Wallenfels I. Vaccinate against uterine cervix cancer or not? [Internet]. Zlaté Moravce: Liga pár páru v SR; 2013 [cited 2019 Feb 9]. Available from: https://www.lpp.sk/ockovanie/434-dat-zaockovat-proti-rakovinekrcka-maternice-alebo-nie. (In Slovak.)

21. Fernández ME, Allen JD, Mistry R, Kahn JA. Integrating clinical, community, and policy perspectives on human papillomavirus vaccination. Annu Rev Public Health. 2010;31(1):235-52.

22. Vadaparampil ST, Malo TL, Kahn JA, Salmon DA, Lee J-H, Quinn GP, et al. Physicians' Human Papillomavirus Vaccine Recommendations, 2009 and 2011. Am J Prev Med. 2014;46(1):80-4.

23. Allen JD, Othus MKD, Shelton RC, Li Y, Norman N, Tom L, et al. Parental decision making about the HPV vaccine. Cancer Epidemiol Biomarkers Prev. 2010;19(9):2187-98.

24. Brewer NT, Gottlieb SL, Reiter PL, McRee A-L, Liddon N, Markowitz L, et al. Longitudinal predictors of human papillomavirus vaccine initiation among adolescent girls in a high-risk geographic area. Sex Transm Dis. 2011;38(3):197-204.

25. Ogilvie G, Anderson M, Marra F, McNeil S, Pielak K, Dawar M, et al. A population-based evaluation of a publicly funded, school-based HPV vaccine program in British Columbia, Canada: parental factors associated with HPV vaccine receipt. PLoS Med. 2010;7(5):e1000270. doi: 10.1371/ journal.pmed.1000270.

26. Woodhall SC, Lehtinen M, Verho T, Huhtala H, Hokkanen M, Kosunen E. Anticipated acceptance of HPV vaccination at the baseline of implementation: a survey of parental and adolescent knowledge and attitudes in Finland. J Adolesc Heal. 2007;40(5):466-9.

27. Salz T, Gottlieb SL, Smith JS, Brewer NT. The Association between cervical abnormalities and attitudes toward cervical cancer prevention. J Womens Health (Larchmt). 2010;19(11):2011-6.

28. Liu A, Ho FK, Chan LK, Ng JY, Li SL, Chan GC, et al. Chinese medical students' knowledge, attitude and practice towards human papillomavirus vaccination and their intention to recommend the vaccine. J Paediatr Child Health. 2018;54(3):302-10.

Received October 5, 2019 Accepted in revised form July 23, 2020 